\title{
Lirg News
}

\section{Annual General Meeting}

The LIRG AGM took place at the Library Association, in London, on Wednesday 23 March 1994. The Chairman's report and the Treasurer's report are reproduced below. The Committee for 1994 consists of Sacha Shaw (Goldsmiths College) Chair, Christine Abbott (Aston University) Treasurer, Deborah Goodall (University of Central Lancashire) Secretary, Monica Blake (Consultant), Hazel Clarke (University of North London), Roz Cooper (University of Northumbria at Newcastle), Eric Davies (Loughborough University), Harry East (University of Westminster), Kay Flatten (University of Central England), Tony Oulton (Manchester Metropolitan University), Philip Payne(Leeds Metropolitan University), Ian Rowlands (City University), and John Sumsion (LISU). Co-opted members are Brian Clifford, Ros Cotton (LIRN Editor) and Peter Taylor (publisher). Anthony Booth continues as IIS observer.

We were pleased to welcome as guests at the AGM Dr Peter Shepherd, Publishing Director at Elsevier Science Ltd, sponsors of the Elsevier/LIRG Research Award, and Geoffrey Smith, Vice Chairman of TC Farries and Co Ltd, sponsors of the TC Farries/LIRG Student Prizes.

The meeting was followed by a talk from John Burchell, Assistant Director at the British Library Research and Development Department, on "library and information science research: a BLRDD perspective". The two winners of LIRG research awards in 1993 then spoke about their research. Andrew Green of the University College of Swansea, winner of the 1993 Daphne Clark Award, spoke about his research into the impact and benefit of appraisal schemes for academic related staff in university libraries. Elisabeth Davenport of Indiana University and Queen Margaret College Edinburgh, winner of the 1993 Elsevier/LIRG Research Award, then gave an interim report on her research entitled "Matrix markets: costing and charging for academic networked services in the UK".

\section{Chairman's Report for $1993 / 4$}

\section{Committee}

The Committee has met four times during the year (June, September, December and March). I should like to record my thanks to all the Committee members for their hard work on behalf of the Group. Particular thanks for all their contributions to LIRG activities go to the three members who are leaving the Committee this year - Micheline Hancock-Beaulieu, Judy Palmer, and Helen Woolston. 


\section{Meetings}

There have been three highly successful half day meetings during the year.

Aberdeen was the venue for the first LIRG Student Prize award meeting in November. An afternoon meeting was held, at which the two winners, Richard Milne of the Robert Gordon University (undergraduate), and Tony Stevens of Sheffield University (postgraduate), both spoke about their research. The meeting also included three short talks on current research at the RGU School of Librarianship and Information Studies. LIRG is grateful to the staff and students of the Robert Gordon University for helping to make the meeting such a success. A full report will appear in a future issue of Library and Information Research News.

In March two half day meetings have been held on the research gaps and research prospects in the Joint Funding Councils' Libraries Review Group Report (Follett report). Over eighty people participated in the two meetings, and lively discussion was stimulated by excellent talks from Frances Krivine, John Sumsion, Don Revill, and John Burchell. The meetings were expertly chaired and introduced by Maureen Castens in London, and by Kevin Ellard in Leeds. A report is being written for publication in LIRN, and for circulation to interested organizations.

\section{Research prizes and awards}

I am delighted to be able to announce that from 1993, TC Farries and Co Ltd will be sponsoring the student prizes for three years. There has been considerable interest in the prizes from the Schools and Departments of Library and Information Science, and we hope to be able to announce the winner of the 1992/3 TC Farries/LIRG undergraduate student prize in the next few days. LIRG is most grateful to TC Farries and Co Ltd for their interest in, and support for, library and information education and research.

The 1993 Elsevier/LIRG Award will be presented this afternoon to Elisabeth Davenport of Indiana University and Queen Margaret College Edinburgh. She will be giving an interim report after this AGM on her project Matrix markets: costing and charging for academic networked services in the $\underline{\mathrm{UK}}$.

A paper by Jo Drew, 1992 Elsevier/LIRG Award winner, was published in LIRN 58, Winter 1993.

The 1993 Daphne Clark Award winner, Andrew Green, of the University College of Swansea, has conducted a survey of the impact and benefit of appraisal schemes for academic related staff in university libraries, and will be speaking after this AGM.

A lack of suitable applications means that, sadly, no Daphne Clark Award is being made for 1994.

\section{LIRN}

LIRN continues to be expertly edited by Ros Cotton, and three substantial issues have been published this year. Monica Blake is relinquishing the post of reviews editor after many years, due to pressure of other work, and a successor is being sought. I should like to thank Monica for ensuring a regular supply of interesting and up-to-date reviews. 


\section{Publicity and stationery}

A new publicity leaflet about the Group has been produced, as well as a new letterhead and logo. The Committee is now looking at a new cover for LIRN to match this new style. Special thanks are due to Judy Palmer who has organized all this and liaised with designer Sean Ryan of Studio 108 on behalf of the Group.

\section{Local activities}

In addition to the meeting in Scotland in November, which we hope may lead to further LIRG Scotland meetings, three LIRG South east meetings have been held in London. Harry East and Yvette Tilson presented results of their research into the liberated end-user in June. In July, Jean Plaister gave a stimulating talk on the outlook for public libraries. Three students from the Department of Information and Communication Studies at the University of North London talked about their research into the media in October.

\section{Other issues}

The Committee has considered a number of other issues during the year. Comments were made on the draft document of British Library Research and Development Department research priorities. In October, Eric Davies and I, representing LIRG, met with the Director and Assistant Directors of the BLRDD. A wide ranging and useful discussion took place, and both organizations have agreed to keep each other informed of their activities. A brief letter was sent in response to the Follett report, drawing attention to the two LIRG meetings in March, and promising that a copy of the full report of those meetings would be sent to the Funding Councils. Contact was made with the Department of National Heritage, indicating LIRG's interest in the proposed Library and Information Commission, and we have now received the Consultation Document, to which we are invited to respond by 22 April. Contact with the Institute of Information Scientists has continued through the attendance at Committee meetings of the IIS observer. The Group's status as an organization in liaison with the Library Association continues to bring benefits, not least the use of meeting rooms, and a grant of $£ 90$, as well as the participation of LA staff in LIRG meetings from time to time. Contact has been maintained with the British Association for Information and Library Education and Research, through the membership of the LIRG Committee of a BAILER Committee member.

Sacha Shaw

Chairman

March 1994

\section{Treasurer's Report 1993}

1. The Group's finances continue to be healthy, with reserves of over $£ 14,000$ at the end of the year. The surplus of income over expenditure (£3884) was almost £2500 more than for 1992 . The high level of surplus is chiefly attributable to increased income from subscriptions. It should be noted however that $£ 1000$ of this surplus is accounted for by the 1994 Elsevier Award: the grant was received from Elsevier in 1993, but had not actually been paid out by the end of the year. 
2. After a full programme of meetings in 1992, the reduced activity in this area in 1993 is reflected in the lower levels of income and expenditure. At the same time the introduction of the student prizes was one reason why expenditure under the "administration" heading - particularly postage - increased. The increased costs of distributing publicity material, and administration associated with LIRN subscriptions, also contributed to the increased expenditure under this heading.

3. In August 1993 the Group's Deposit account was changed to a Capital Reserve account, offering a higher level of interest (currently 3.25 per cent). To some extent the additional interest earned has been eroded by bank charges, which are incurred on all transactions. However, from March 1994 organizations such as ours are to be offered free banking, so this expenditure should be minimal in 1994.

4. Roz Cooper, LIRG's personal membership secretary, has expended considerable effort over the last year collecting unpaid personal subscriptions and bringing the membership files up to date. The number of personal members as at 31 December 1993 was 101, compared with 121 at the same time last year.

5. There were 115 institutional subscriptions to LIRN at the end of the year: 76 UK and 39 overseas ones. These figures represent at net increase of 7 UK subscriptions, and a reduction in overseas ones of 8. The institutional profile continues to be a good mix of academic and public libraries, but there are disappointingly few subscriptions by special libraries.

6. Given the healthy balance at the end of the year the Committee has decided to freeze membership rates for 1994 , at $£ 15$ for personal members, reduced to $£ 7.50$ for students and the unwaged. LIRN subscription rates also remain the same as 1993: $£ 35$ for UK institutions and $£ 40$ for overseas ones.

7. LIRN charges of $£ 826$ cover the production costs of the Spring and Summer issues, 56 and 57. Charges for Issue 58 will be incurred in 1994.

Christine Abbott

LIRG Treasurer

March 1994 